\title{
Islamic Spirituality, Resilience and Achievement Motivation of Yemeni Refugee Students: A Proposed Conceptual Framework
}

\author{
Manal Ali Ahmed ${ }^{1}$, Sahabuddin Hashim ${ }^{2}$ and Nik Rosila Nik Yaacob ${ }^{3}$ \\ USM, Universiti Sains Malaysia \\ Penang, Malaysia \\ 1https://orcid.org/0000-0001-6497-3256 \\ 2https://orcid.org/0000-0002-2014-1973 \\ 3https://orcid.org/0000-0002-3972-5688
}

\begin{abstract}
The present study aims to improve Yemeni refugee students' achievement motivation by introducing the construct of Islamic perspective of spirituality and resilience. The issue of achievement motivation of students has been a concern in educational psychology circles. However, it appears to be mostly not concerned on refugee students. From the previous literature review finding, the study supports the belief that Islamic spirituality effects on refugee students because it encompasses the whole aspects of the person life. It also describes the role of positive outcomes of resilience on refugee students. To achieve this, a new theoretical framework is proposed to describe how spirituality from Islamic perspective and resilience can impact on achievement motivation of Yemeni refugee students. This contribution to the body of literature research aims to support theoretical and empirical research and provide a more explanation of the correlation between these three concepts. The study has particular implication for research, to help parents and teachers to improve achievement motivation through improve Islamic spirituality and resilience of refugee students. Finally, the paper concludes by calling for future research based on the gaps identified in the current study to investigate the relationship between Islamic spirituality, resilience, and achievement motivation.
\end{abstract}

Keywords: achievement motivation; spirituality; resilience; Yemeni refugee students

\section{Introduction}

The United Nations High Commissioner for Refugees (UNHCR) reported that around twenty people every minute become a refugee worldwide. Globally, the number of refugees totalled 25.4 million people worldwide at the end of 2017 (United Nations High Commissioner for Refugees [UNHCR], 2018). An increase in the number of Yemeni people who are refugees is a new problem that started 
in 2015 because of the war and related circumstances in Yemen. Many Yemeni people fled their homes seeking safe places or because they lost their job. A large number of Yemeni refugees escaped to countries around the world such as the Kingdom of Saudi Arabia.

There are high rates of psychological problems that are faced by the refugees who move to new countries (Van der Veer, 1992). According to Jaranson et al. (2004) and Robertson et al. (2006), refugees face psychological problems such as anxiety, depression and PTSD. Additionally, the psychological factor is one of the factors that may obstruct new refugees from adjusting in the new country (Robinson, 2013). Similarly, several types of problems have been faced by Yemeni refugee students such as psychological, economic, social and educational. Referring to educational psychological issues, achievement motivation is considered to be of critical concern in this area (Bal-Taştan et al., 2018). However, with this increase in the number of Yemeni refugees, no psychological or educational research studies have yet explored the achievement motivation of Yemeni refugee students according to the best of the researcher's knowledge.

According to Shekhar and Devi (2012) and Quispe-Bendezú et al., (2020), achievement motivation is an active matter in the area of education. Studies on achievement motivation have an extensive and extended history. Moreover, achievement motivation has become an extensively studied concept in the psychology field and it is still an active field of study, especially in the area of educational psychology (Chen, Elliot \& Sheldon, 2019). Poledňová, Stránská and Niedobová (2014) observed that the achievement motivation topic has a critical pertinent focus within the psychology scope.

Many studies like Brunstein and Heckhausen (2018) and Awan, Ghazala and Anjum (2011) have been published in order to determine factors that influence achievement motivation of the students. The studies identified diverse factors such as the social-economic status of the family, the residential place of the student and the effort put in by the student. However, according to Wong and Schweitzer (2017), the information on the factors and resources of achievement that affect refugee adolescents is still limited.

Extensive research has been done on achievement motivation such as the studies conducted by Poledňová et al. (2014) and Dinesh and Kiran (2018), with less attention given to realizing what the potential impact of spirituality and resilience is. Therefore, research into spirituality and resilience in relation to achievement motivation is still limited in the previous research studies. It is critical to comprehend the factors that may impact on the achievement motivation of refugee students in their schools.

Spirituality helps people adapt to challenges (Faigin \& Pargament, 2011). Pulla (2014) mentioned that spirituality is essential for people. Gozdziak and Shandy (2002) stated that although there is significance in the role of religion and spirituality among refugees, it has been largely ignored by researchers. Spirituality is recognized as an essential element when individuals face 
difficulties (Faigin \& Pargament, 2011). Similarly, Shaw, Peacock, Ali, Pillai, \& Husain (2019) stated that spirituality could help refugees to face and adapt to the adversities they encounter.

According to Hutchinson and Dorsett (2012), spirituality is a belief in God. Florczak (2010) asserted that spirituality is optimism, bravery and selftranscendence. Crawford, Wright and Masten (2006) defined spirituality as a process that promotes resilience in individuals who were exposed to adversities in their lifespan. The discussion of the definition of spirituality above shows that the term spirituality is comprised of many aspects.

The early research studies on resilience concentrated on how adolescents encounter the difficulties in their life. Researchers have described resilience in many forms such as Kobasa (1979) with hardiness, Garmezy (1993) as an evaluation of facing adversity and Rutter (1987) who affirmed it to be a successful adaptation. Furthermore, Rak and Patterson (1996) declared resilience to be the ability of people who have encountered the risk factors to overcome difficulties and avoid negative outcomes such as behavioral problems and academic difficulties.

Most of the resilience studies such as those by Peres, Moreira-Almeida, Nasello, \& Koenig (2007) and Isokääntä, Koivula, Honkalampi and Kokki (2019) have focused on traumatic events and other diseases. Betancourt and Khan (2008) pointed out that the previous literature focused on the risks that refugees faced with less attention paid to their resilience. Pieloch, McCullough and Marks (2016) stated that while refugees represent a large part of society in new countries, it is essential for education professionals to understand how the resilience of refugees can help in terms of their adaptation positively.

The purpose of the present article is to highlight a conceptual framework of spirituality from Islamic perspective, focused on the resilience and achievement motivation of Yemeni refugee students in Saudi Arabia.

\section{Background}

According to UNHCR (2016), since the fighting increased in late March 2015, Yemen continues to crumble. Absence of security and violence have led to the displacement of some of the population both internally and externally. Khan (2018) stated that the disaster in the Republic of Yemen is considered to be one of worst disasters worldwide. Similarly, UNHCR (2020) stated that:

"The humanitarian crisis in Yemen remains the worst in the world."

More than four years of conflict has led to more than 4.3 million Yemeni people being forced to flee (UNHCR, 2020). Approximately 166,658 refugees from Yemen have arrived in countries in the Gulf region because of the adversity in Yemen.

Most of the refugees reside in countries near to their countries of origin (Shaw et al., 2019). Accordingly, most of Yemeni refugees fled to the Kingdom of Saudi 
Arabia because of the Saudi geographic location in terms of Yemen (UNHCR, 2016). Despite the passage of more than five years referring to the war in Yemen, the ignorance of the disaster in Yemen continues.

Patel et al. (2017) stated that there is a dearth in the research that studies the influence of the war crisis on the achievements of the refugee students. Although there has been a wide range of research relating to achievement motivation in school, very few studies focus on the factors that may increase the achievement motivation of refugee students (Pastoor, 2017). Further, previous studies have determined that there are many factors affecting achievement motivation such as socioeconomic and psychosocial factors. Psychology and adaptation could be associated and relevant to achievement motivation (Anderman \& Anderman, 1999).

After going over the scientific studies and literature influencing achievement motivation, the researcher found that the previous literature did not focus on the influence of both spirituality and resilience on achievement motivation. Harris (2016) obviously mentioned the lack of research discussed the effect of spirituality and resilience when coping with the challenges faced in life.

Spirituality is viewed as significant and it has a very important role in many fields such as education (Wright, 2003) and psychology (Rego \& Nunes, 2019). However, most of the previous studies relating to spirituality do not contain studies that are directly linked to achievement motivation. Kim and Esquivel (2011) highlighted the need for more research and an understanding of how spirituality affects the learning process.

Resilience can positively affect an individuals' ability to overcome the difficulties encountered when achieving personal, professional or academic goals (Smith, Tooley, Christopher \& Kay, 2010). There is a lack of previous works that have examined the resilience within Arabic countries (Ungar, 2012).

According to Waxman, Gray and Padron (2003), there is a need for studies to identify the indicators of resilience used to evaluate the impact of the students' affective and motivational results. In accordance with the previous studies, there is a dearth in the studies that seek to elucidate the relationship between resilience and the achievement motivation of the refugees (Hutchinson \& Dorsett, 2012).

\section{Literature Review}

\subsection{Achievement Motivation}

Beginning with the Theory of the Hierarchy of Needs by Maslow (1954) which classified human motivation as a sequence of needs. Furthermore, Helgeson (2005) motivation as a desire to achieve an aim which is significant to humans. Akram and Ghani (2013) shared Helgeson (2005) view on motivation. They defined motivation as a desire to perform an aim or a drive related to a certain behavior. Similarly, Dörnyei and Ushioda (2011) indicated the significance of motivation that derives from the inside leading to shape motivation of individual. 
The definition of achievement motivation as presented by McClelland, Atkinson, Clark, \& Lowell, (1953) is:

"The need to do something well in competition with a standard of excellence."

In a later period, achievement motivation has been extended by McClelland (1961) to include the striving of an individual for excellence, shown through effort when they are coping with hardship. Furthermore, the need in McClelland's theory for achievement is deeply correlated to education conceptions. The concept of achievement motivation proposed by McClelland is that when a person has a strong need, the effects of this need motivate a person to behave in the manner which means that their needs are met.

\subsection{Spirituality}

Various definitions of spirituality have been included in the previous research literature. Zsolnai and Illes (2017) asserted the definition of spirituality as a complex concept, with many variations across different cultures and many dimensions. The different understandings and interpretations of spirituality are because of the differences in the viewpoints, sources, and considerations involved.

Furthermore, Landrum (2000) defines spirituality as the valuing of an individual, in addition to examining or expressing a greater construction that could be used to view human life through it. Stokley (2002) had another insight into the definition of spirituality, which is the viewpoint through which actions and behavior are determined by others in the community. Kim and Esquivel (2011) described spirituality as an ingrained aspect of the nature of human beings that is revealed during the adolescence period in which the adolescents seek transcendence, purpose in life and meaning.

It is obvious from the aforementioned literature that there is no consensus on the definition of spirituality. Although there is a degree of complexity and no agreement on the definition of spirituality, many of the definitions are centered into two aspects: an individual's connection in order to transcend and how it is central in an individual's life experiences.

From the Western perspective, there are different views of the spirituality concept and the religion definition. Barker (2008) summarized these different views of spirituality and religion and classified the relationship between them into five models. The first relationship classification is that there is no difference between religion and spirituality and the concept is used interchangeably. The second relationship is that spirituality is a sub-division of religion. The third relationship is that religion is a subsection of spirituality. The fourth possibility is that there is a difference between religion and spirituality. Lastly, there is an overlap between religion and spirituality. Figure 1 summarizes the relationship between spirituality and religion based on Barker (2008) model. 


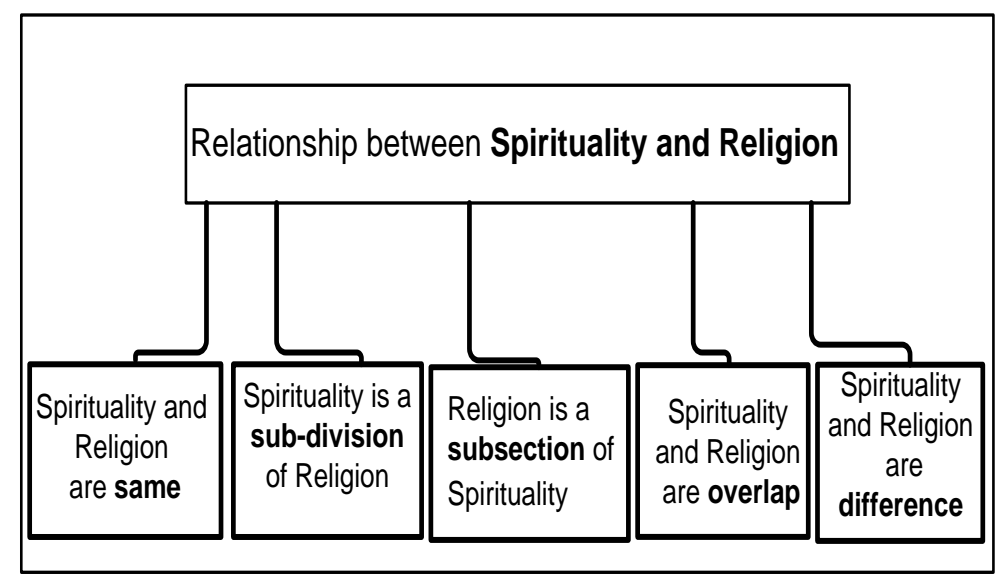

Figure 1: The relationship between spirituality and religion based on Barker (2008) model

\subsection{Spirituality from Islamic perspective}

Islamic religion has its own view of spirituality that differs from that of other religions. According to Nasr (1987), from an Islamic viewpoint, the distinction between religion and spirituality does not exist. Spirituality is an integral part of religion for Muslims (Rassool, 2000). Pahlevan and Ong (2018) mentioned that the spiritual dimension is considered to be a fundamental characteristic in a Muslim society. In addition, spirituality in Muslim life is important and cannot be ignored. Sani and Maharani Ekowati (2019) revealed that spirituality in Islam ensuring that every action does is in accordance with Allah's pleasure.

Furthermore, the meaning of Islam in the Arabic language is submission to the will of Allah (Husain, 1998). In Islam, the word Islam for Muslims means whole submission to the will of Almighty Allah and the worship of Allah alone. In Islamic context, religion is a Muslim way of life (Mahudin, Noor, Dzulkifli \& Janon, 2016).

Based on Altareb (1996), Islamic spirituality provides the instructions and directions needed to increase Muslim spirituality. Muslims attain the highest level of spirituality if individual Muslims conduct their life and activities related to the purpose of obeying God (Islahi, 1989). In the same context, Al-Ghazali (1986) declared that spirituality is gained through the practice of Islamic instructions. Briefly, the concept of spirituality and religion in Islam is clear and there is a consensus between scholars. Additionally, Islam has a distinctive viewpoint on spirituality that differs from Western perspectives.

In terms of the references to Islamic spirituality, the sources of spirituality in Islam are based on a solid foundation of Islamic law (Sharia) origins from the Muslims' Holy book (The Holy Qur'an) and the habitual practice (Sunnah) of Prophet Mohammed (peace be upon him). These make up the fundamental sources of the curriculum of Muslims. Therefore, in terms of the source, spirituality in Islam is distinguished from spirituality in the Western perspective. 
Nasr (1981) classified spirituality as being based on three basic notions: submission (Islam), faith (Iman) and perfection (Ihsan). Islam includes the obligation to worship as a Muslim individual. Furthermore, Muslims submit through the practice of the five pillars of Islam, which is the testimony of faith, prayer five times a day, fasting during one month every year in Islamic calendar (Ramadhan), alms-giving (Zakat), and pilgrimage (Hajj) (Hamdan, 2010). The second concept is Iman, which refers to the Muslim's belief in God and the other pillars of faith. Nisar, Farwa and Nadeem (2015) described how faith affects spirituality: "Faith provides a skeleton for the soul. Just as bones give a structure to a frail envelope like the skin to carry the body, in a similar manner does faith add substance to the spirit". The third one is Ihsan, which refers to the highest level of spiritual distinction that Muslim individuals are supposed to have (Mahudin et al., 2016). All these three concepts are related together to shape the whole Muslim individual. Thus, it can be observed that the perspective of spirituality in Islam means to be close to Allah and to prove that through good deeds that please Allah.

From a wider angle, human beings are created from two components that interrelated that can never be separated from each other: body and soul (AlGhazali, 1986). Al-Ghazali (1989) explained that in Islam, the soul is the source of happiness for a Muslim individual and it has a high value in Muslim individual life; thus the body is considered to be only a container for the soul. Therefore, Islam pays particular attention to the soul. It seeks to purify and refine it, because of its impact on a person's life.

Because of the importance of the soul, Allah made one of the reasons behind the mission of the Prophet Muhammad (May Allah peace be upon him) to refine the soul. It is enshrined in the Qur'an:

"...when He sent them a messenger from themselves, reciting to them His signs and praise them and teach them the Book and wisdom that had previously shown in error" (The Qur'an 2: 164).

The mission of the Prophet Muhammad (peace be upon him) was comprehensive in all aspects of life, including spirituality. Moreover, Islam focused on the importance of self-purification and refinement. Islam is connected to happiness in this world and success in the hereafter by adhering to the instructions given. Furthermore, it asserts that unhappiness in the world and losing out in the hereafter is a consequence of not following Allah's orders. Allah said:

"Whoever purifies it has succeeded; and failure is the lot of whoever corrupts it" (The Qur'an 91:9-10).

A lot of Muslim scholars and researchers have explained the meaning of the verse as Muslims purifying their souls of sordid morals and vices (Al-Jawziyyah, 2006). 
Furthermore, the concept of spirituality (ruhaniyyah) in Islam focuses on the relationship between a Muslim's purpose of life and their religious rituals. Allah mentioned in the Qur'an that:

"A Muslim's purpose of life is to worship Allah" (The Qur'an 51:56).

In Islam, people are created to worship Allah and to obey Allah's instructions. Furthermore, the Holy Qur'an has pointed to the word spirit (ruh) in the following verse as the secret of life:

"And they ask you about the ruh. Say: The ruh is one of the commands of my Lord, and you are not given aught of knowledge but a little" (The Qur'an 17:85).

In this regard, the Messenger Muhammad (peace be upon him) said:

"Allah shall not look at your bodies or your faces, but rather looks into your hearts" (Muslim, Book 32, Hadith 6220).

As Grine, Fares, \& Meguellati (2015) stated, individual Muslims have to perform religious rituals that are considered to be a periodic nourishment for his/her spirit that help to purify his/her heart from sin. Hawa (2006) asserted that Muslims have to clean their spirits through conducting prayer, fasting, reciting the Qur'an and other rituals. According to Nasr (1987), spirituality in Islam represents the relationship between humans and Allah that influences the self-esteem of the person, linking with others and nature.

From an Islamic point of view, spirituality covers all Muslim life aspects. According to Rassool (2000), Islam provides a spiritual path to salvation and spirituality is a result of religious thinking and practices in Islam. In Islam, it is obvious that the worship of Allah is the road that needs to be journeyed to get to spirituality. Abu Dharr reported that the Messenger of Allah, peace and blessings be upon him, said:

"Be mindful of Allah wherever you are, follow a bad deed with a good deed and it will erase it, and behave with good character toward people" (Tirmidhi, Vol. 4, Book 1, Hadith 1987).

In the light of this hadith, Islamic spirituality is defined as a concept that has been included in the fearing (taqwa) of Allah. Taqwa has been clarified as putting a protective barricade between yourself and Allah's penalty. Practicing Islam is done by doing good deeds and being involved in society while representing good morals.

In summary, it is obvious that spirituality is related to the connection between Allah and individual Muslims. A Muslim purifies him/herself through performing daily and periodic religious rituals. It is clear that Islam does not interpret spirituality in isolation of everyday actions and religious rituals. In Muslim life, all activities, whether small or big, must be in accordance with Allah's pleasure. Performing prayers, reciting the Qur'an and attending a mosque are 
examples of strengthened spirituality. Thus, it can be observed that the perspective of spirituality in Islam means to submit to Allah and to be close to Him, to love Him and to prove that through deeds that please Allah. Briefly, based on this concept of spirituality in Islam, all actions agree with the pleasure of Allah and the feeling of connectedness with Allah and loving Him.

Furthermore, with regard to Islamic spirituality that has been reviewed in the aforementioned literature, the current research sets out to prepare the theoretical framework of Islamic spirituality after reviewing spirituality research in order to define the concept of spirituality from an Islamic point of view in the theoretical framework.

\subsection{Resilience}

Resilience is considered to be a significant concept in the context of adapting to the challenges of life. The term resilience has been defined by Richardson, Neiger, Jensen and Kumpfer, (1990, p. 34) as:

"the process of coping with disruptive, stressful, or challenging life events in a way that provides the individual with additional protective and coping skills than prior to the disruption that results from the event".

However, Wolins and Wolins (2010, p. 5) defined resilience as the:

"Capacity to bounce back, to withstand hardship, and to repair yourself".

Similarly, Masten (1994) provided the concept of resilience as a pattern that may be adjusted in the end in spite of the existence of risks, pressure or misfortunes in life. Dyer and McGuinness (1996, p. 276) assert that resilience is:

"The ability to bounce back from misfortune".

From the previous view of resilience definitions, it is obvious that the term resilience has different meanings based on which perspective is used. However, all of the definitions include the meaning of resistance.

Dyer and McGuinness (1996) consider resilience to be a process where individuals spring back from difficulty and carry on with their lives. Furthermore, this process is dynamic and it is affected by protective factors. Correspondingly, Masten (1994) described resilience as a process. Subsequently, Masten (2001) emphasized resilience as a set of processes between individuals and the environment. In the same context, Luthar, Cicchetti and Becker (2000) defined resilience as a process used to adapt positively with difficulty. The description of resilience follows the same lines as those of Clinton (2008) study. Resilience has been defined as a type of adaptive behavior or the ability to manage in the environment.

According to Southwick and Charney (2012, p. 6), resilience is defined as:

"the process of adapting well in the face of adversity, trauma, tragedy, threats and even significant sources of stress - such as family and 
relationship problems, serious health problems, or workplace and financial stresses".

It is obvious from the literature and previous studies that resilience changes according to the adversities faced (Werner \& Smith, 1992). Additionally, resilience is identified as a dynamic and complex process that leads to mitigation when facing stresses (Bonanno, Galea, Bucciarelli \& Vlahov, 2007). Increasingly, there is an indication that resilience is a multidimensional and dynamic process in the face of misfortune (Luthar et al., 2000). Resilience is considered to be the result of the interaction process between the genetic, biological, psychological and sociological factors in the context of environmental support (Henry, 1999).

Resilience is defined by Luthar et al. (2000, p. 543) as:

"A dynamic process encompassing positive adaptation with the context of significant adversity".

Luthar et al. (2000) theory declares that in order to be resilient, one must have met two conditions: exposure to a critical threat or severe hardship and the attainment of a positive adaptation. Furthermore, she proposed focusing on the mechanisms of the variables that perform as either a protective or risk factor (Luthar et al., 2000, Luthar, Sawyer \& Brown, 2006).

Neenan (2017, p. 17) defined resilience as:

"a set of flexible cognitive, behavioral, and emotional responses to acute or chronic adversities which can be unusual or common place".

Additionally, Bernard (2004, p. 43) summarized resilience as:

"the preponderance of resilience related research identifies resilience as a universal, developmental capacity of every human being".

The previous section has outlined the concept of resilience as defined according to different facets of the previous research. Furthermore, the way that researchers have defined the term resilience is similar and has been come in interchanged words. Resilience is described in different terms such as positive coping, adaptation and persistence.

\section{Relationships among Achievement Motivation, Spirituality, and Resilience}

This section will review the related previous research studies on the relationship of achievement motivation, spirituality, and resilience.

\subsection{Spirituality and Achievement Motivation}

Many studies have focused on spirituality and how it relates to social outcomes, well-being and coping. However, very few studies have been found that have focused specifically on spirituality and achievement motivation. Kim and Esquivel (2011) explained that the research revealed that spirituality promotes the 
capability of people to face adversity and that it improves the student's performance in academic learning. It is claimed by Johnson (2008) that the interest in studies concerning spirituality and academic performance has just started and that it has been rising.

Some studies have explored related constructs referring to spirituality, achievement motivation and refugee students. For example, Bowen and Cheng (2017) investigated the impact of spiritual cues on non-cognitive skills. The authors conducted a research study looking at 180 secondary school students but there were no refugees in the population. The study found that the self-regulatory capabilities of students are boosted by increasing their sense of religion, the predictors of educational achievement and increasing their political tolerance. Davis (2017) mentioned the influential role of intrinsic and extrinsic motivation on achievement. Generally, the literature has shown there to be few studies on the area concerning the relationship between refugees and their religiosity (Ennis, 2011).

\subsection{Resilience and achievement motivation}

There is a lack of studies that are concerned with refugee resilience (Hutchinson \& Dorsett, 2012). The current studies recommend that there is a need to understand what the strengths and skills are of refugees in order to promote refugee resilience (Bartlett, Mendenhall \& Ghaffar-Kucher, 2017). Darychuk and Jackson (2015) used interviews to reveal how female refugees navigate the influences of gender within community resilience at UNRWA health centers. The study reached the result that there is a significant role played by the presence of a safe place for refugees and showed the resilience of Palestinian women.

Furthermore, Dinesh and Kiran (2018) studied achievement motivation and selfconcept using Achievement Motive Test (ACMT) and a population of secondary school students. The results showed there to be no significant difference between high achievers and low achievers concerning the achievement motivation of the study sample. Additionally, the scores of the high achievers among secondary school students were a little higher than the low achievers concerning achievement motivation.

\section{Proposed Theoretical Framework of the Current Study}

The theoretical framework of this study is based on the foundation of three major theories. The perspectives are spirituality from an Islam perspective, the Resilience Theory by Masten (2014a) and the Achievement Motivation theory by Atkinson (1964). It is believed that the synthesis of these theories and perspectives provides a proper reflection of the purpose of this study.

The first central conceptual component for the present research is guided by spirituality from Islamic perspective. In Islamic literature, Islam is defined in the Arabic language as submitting to Allah - glory be to Him - and complete obedience to His orders. According to Nasr (2002), the meaning of Islam is "surrender" as mentioned in (The Qur'an 4:125): 
"Whose way is better than that of the man who has submitted to God, and does good, and who follows the creed of Abraham the upright?"

Muslims are requested to follow Abraham and to be in a state of total surrender like him, in addition to following the Prophet Muhammad (peace be upon him) who said:

"...By Allah, I am more submissive to Allah..." (Al-Bukhari, Vol. 7, Book 62, Number 1).

The submitting and surrendering to Allah is including Islamic beliefs, the consequent orders, and duties that a Muslim must do according to the pillars of Islam and the pillars of faith themselves to the highest level that is called Ihsan;

"to worship Allah as if you see Him, and if you do not see Him, He will see you" as mentioned in the famous hadith called the "hadith of Gabriel" (Al-Bukhari, Vol. 6, Book 60, Number 300).

A Muslim is obliged to submit to and completely surrender to the orders and instructions of Allah which are mentioned in the legislation of Muslims. Allah the Exalted said:

"So take what the Messenger assigns to you, and deny yourselves that which he withholds from you. And fear Allah" (The Qur'an 59: 7).

The meaning of this verse as explained in the interpretation of Ibn Kathir is that:

"whatever the Messenger commands you, then do it and whatever he forbids you, then avoid it. Surely, He only commands righteousness and forbids evil" (Abdul-Rahman, 2009, p.51).

Furthermore, the essential meaning of worship is declared as practicing from a firm belief that the One who orders it is Allah Almighty and that the Prophet (peace be upon him) delivered its method to us in detail. Hence worship falls under the concept of absolute submission to Allah. This surrender is to Allah who is closer to us than the jugular vein as mentioned in the (The Qur'an 50:16):

"we are closer to him than [his] jugular vein".

The more one submits by worshiping Allah, the closer we are to Him as mentioned in (The Qur' an 96: 19):

"and bow down in sajdah, and come closer".

There is also the saying by the Holy Prophet (peace be upon him):

"The closest that a servant can be to his Lord is when he is in prostration.

Therefore, make abundant supplications (i.e. while prostrating)"

(Muslim, Book 4, Hadith 979).

The meaning of "closeness" has also been stressed during the migration to Madinah. The Prophet said to his friend Abu Bakr "Allah is with us" as mentioned 
in (The Qur'an 9:40). Maintaining closeness to Allah is very important for the purification of the soul as mentioned in the Qur'an and hadiths.

The closeness of Allah makes the love of Him greater as stated in the Qur'an:

"Say: If you love Allah, follow me, and Allah will love you" (The Qur'an 3:31).

The closer a Muslim approaches His Lord with acts of worship and obedience, to implement his orders and to avoid his prohibitions, the more his love for Him and so the greater his spirituality. Worship brings together the origin of the goal of love with the goal of submission. This is stated clearly in the hadith:

"When My servant approaches Me through good works, then I love him..." (Al-Bukhari, Vol. 8, Book 76, Number 509).

A Muslim strives to come closer to Allah by performing worship like voluntary prayers. Allah will bring him closer to Him and his level will be raised from Eman (belief) to Ihsan. In other words, the path to gaining the love of Allah is through rituals and good deeds which bring pleasure and enhance spirituality.

In the current research, spirituality as an Islamic concept originated from two sources. The first belongs to the Qur'an which discusses the three Islamic themes of submission to Allah, love and closeness. The second source comes from the hadiths which explain how to apply the aforementioned Qur'anic themes. Both sources are essential when developing Muslim spirituality from an Islamic background. Consequently, Islamic teachings could be applied in the framework of submission to Allah, love and closeness which represents a comprehensive umbrella of Islam. It can be seen what the consequence are; there is a fear of Allah when one does not perform orders.

According to this view of the concept of spirituality in Islam, submission to Allah, love and closeness may serve as a useful framework for understanding Muslim spirituality.

The next theoretical framework is Masten's theory, which has been synthesized to show the conceptual framework of resilience that serves as the basis of resilience in this study.

Resilience stems from the nature of a person's ability to adjust to different circumstances (Masten, 2001). According to Masten, Morison, Pellegrini and Tellegen (1990), resilience describes phenomena by dividing them into three types. The first phenomenon is about persons who have knowledge of successful adaptations in spite of a high risk. The second phenomenon is about persons who are resilient to pressure and the third phenomenon is about persons who improve after a traumatic experience. This theory supports the purpose of the current research study to examine resilience and to assess whether there is a significant relationship between resilience with the other variables in the study. 
Later, Masten studied resilience in youth refugees that were exposed to war (Masten, 2014b). Masten also studied resilience in people in war-torn circumstances and related issues like homeless street-children in Nepal, famine in the Niger and the war in Afghanistan (Panter-Brick, Grimon \& Eggerman, 2014). According to Masten (2014b), an adaptive system is important in youths because it describes their motivation system. Furthermore, Masten (2001) stated that if youths do not appear to be resilient in their life experiences, then this means that "basic resources nor the opportunities and experience that nurture the development of adaptive systems" do not exist in the youths. Masten, Cutuli, Herbers and Reed (2009) recommended avoiding harm to, restoring, or recompensing for any pressures in essential systems.

Based on theory of Masten et al. (2009), an individual is considered to be resilient if two conditions are fulfilled: a positive adaptation in the development of the individual and risk or threat to the individuals' positive adaptation. The positive adaptation is an alignment of the human adaptation system and developmental tasks. The expectations of a certain culture within the individuals' behavior when across diverse periods of age and in different situations consider the developmental tasks of the individual. Furthermore, Masten et al., (2009) mentioned that essential adaptation systems are a compromise between many relations such as attachment associations, families, parenting, spirituality, religion and formal education systems. In the context of refugees, Masten (2014b) stated that refugees are varied in how they perform in different areas of their life such as in school and other places, including the effect of resilience.

The last theory is the theory of achievement motivation that was developed by Atkinson (1964) which is one of the most famous theories on achievement motivation. The achievement motivation theory frames the theoretical framework for achievement motivation of this study. This theory explains achievement motivation as a tendency towards positive motivation and the tendency towards negative motivation respectively. The motive of the individual is considered to be positive if they are motivated toward success (Ms) and their motivation is considered to be negative if they are motivated to avoid failure (Mf). More deeply, achievement motivation theory is a theoretical model that proposes

"to explain how the motive to achieve and the motive to avoid failure influence behavior in a situation where performance is evaluated against some standard of excellence" (Atkinson, 1957, p. 371).

In addition to the two motive factors, Atkinson (1957) defined the tendency to complete an achievement-oriented task in terms of the four factors that are the likelihood of success, the likelihood of failure, the incentive of success and the incentive of failure.

According to Atkinson and Feather (1966), the achievement motivation of individuals is derived from two types of motives; the tendency to achieve success and the tendency to avoid failure in different levels of task. The theory of achievement motivation by Atkinson and Feather (1966) places emphasizes on the competition between the motivational tendencies that are existed in every 
achievement-oriented activity. Atkinson and Feather (1966, p. 328) proposed that behavior consists of three components, which are:

"motive, expectancy, and incentive".

The motive of an individual to achieve success is related to:

- The motive or need to achieve success: This motivation refers to the ability of an individual to perform a task actively in order to achieve success. Consequently, Motivation to Success is a result of another motivation to avoid failure.

- The strength of expectancy or the probability of success: The probability of success in relation to a task is based on an assessment performed by the individual that is performing a task. The probability of success is between very low to very high, and it depends on the importance of success to the individual.

- The incentive value of success: When the level of task difficulty increases, the incentive is required to increase in order to maintain a high level of achievement. Difficult tasks associated with a low incentive value do not motivate the individual to achieve success. The individual himself can assess the level of task difficulty and incentive.

Moreover, the motivation to achieve success and the motivation to avoid failure are related. If the individual is motivated by success, he/she will perform tasks with a probability of success that is equal to the probability of failure, and where the value of the incentive is high. If an individual is motivated from a fear of failure, he/she will avoid performing tasks that are equal in terms of their probability of either success or failure. Moreover, he/ she will choose easier tasks to reduce the probability of failure or more difficult tasks where failure can be attributed to the difficulty of the task.

In other words, if the motive of an individual to achieve success is higher than the motive to avoid failure, then the individual's expectation will be achieved and they will perform the task well. In contrast, if the motive of an individual to avoid failure is greater than the motive to achieve success, then the individual's expectation will be the fear of failing to perform the task.

Depending on the aforementioned theories, if individuals who escape their country because of war have a closeness to Allah and the ability to face things positively in life, then this may be a sign of the presence of an achievement motivation represented by a tendency to achieve success or to avoid failure. In contrast, if individuals who have suffered due to war do not have sufficient connectedness to Allah and the capacity to cope, then this will lead to a lack of a desire to achieve in life. Figure 2 summarizes the theoretical framework of the present study. 


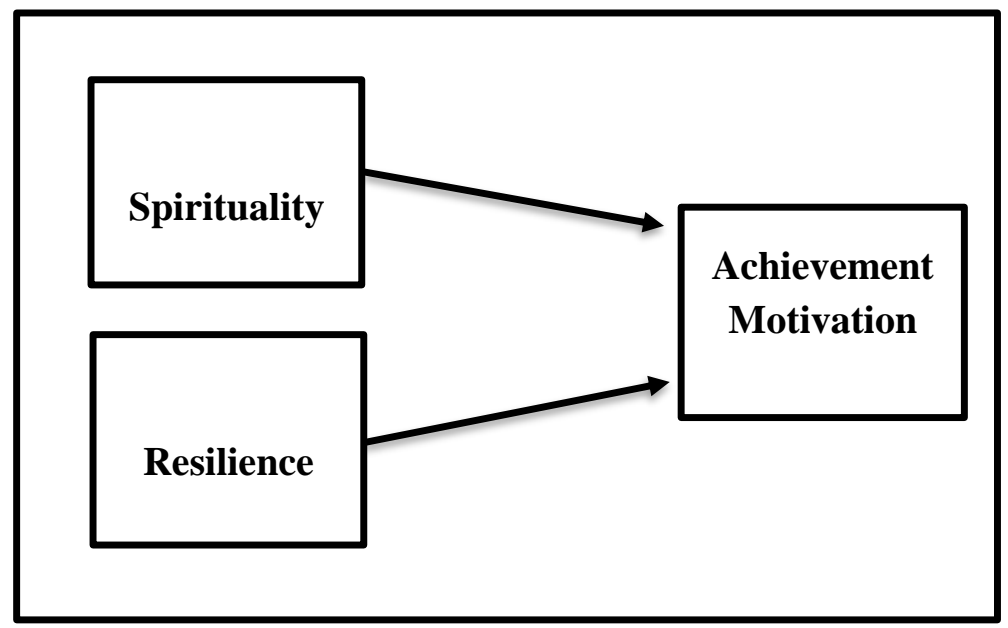

Figure 2: Theoretical framework of spirituality, resilience and achievement motivation

\section{Conclusion}

In conclusion, the current study was an attempt to propose a new theoretical framework that outlined above to define and illustrate the concept of achievement motivation of Yemeni refugee students by introducing the construct of Islamic perspective of spirituality and resilience with paying particular attention on their effects on achievement motivation. Further, most of previous spirituality studies have addressed spirituality from a western point of view, which is different from the Islamic viewpoint of spirituality. Consequently, this study attempts to fill the literature gap on spirituality from the Islamic perspective and proposes a new conceptual framework to enrich the understanding of the Islamic spirituality and resilience and its contribution to achievement motivation. This study will also help parents and teachers to improve Islamic spirituality and resilience in refugee students. Further theoretical clarification based on the current conceptual framework may provide western researchers with deep knowledge of the Islamic spirituality in Muslim society with particular emphasis on the soul as a source of happiness. Additionally, the present study calls researchers to develop models of Islamic spirituality that are appropriate in Muslim countries.

\section{References}

Abdul-Rahman, M. S. (2009). Tafsir Ibn Kathir Juz'28 (Part 28): Al-Mujadila 1 To At-Tahrim 12 (Vol. 28) (2nd Ed). MSA Publication Limited.

Akram, M., \& Ghani, M. (2013). The relationship of socioeconomic status with language learning motivation. International Journal of English and Education, 2(2), 406-413.

Al-Bukhari, M. I. (1997). The Translation of Sahih AlBukhari. (Muhsin Khan (Trans.), Ed.). Riyadh, KSA: Darussalam

Al-Ghazali. (1986). Ihya' 'Ulum al-Din. Edited by Zayn al-Din Abi al-Fadl 'Abd al-Rahim ibn al-Husayn al-'Iraqi (Vol. 4). Bayrut, Lebanon: Dar al-Ma'rifah.

Al-Ghazali, A. (1989). Al-Mizan. Beirut, Lebanon: Dar Al Kotob Al Ilmiyah.

Al-Jawziyyah, I. I. Q. (2006). Spiritual Disease and Its Cure. London, UK: Al-Firdous Ltd.

Altareb, B. Y. (1996). Islamic Spirituality in America: A middle path to unity. Counseling and Values, 41(1), 29-38. doi:10.1002/j.2161-007x.1996.tb00860.x 
Anderman, L. H., \& Anderman, E. M. (1999). Social predictors of changes in students' achievement goal orientations. Contemporary educational psychology, 24(1), 21-37. doi:10.1006/ceps.1998.0978

Atkinson, J. W. (1957). Motivational determinants of risk-taking behavior. Psychological Review, 64(6), 359-372. doi:10.1037/h0043445

Atkinson J. W. (1964). An introduction to motivation. Van Nostrand, Princeton, NJ.

Atkinson, J. W., \& Feather, N. T. (Eds.). (1966). A theory of achievement motivation (Vol. 66). New York: Wiley.

Awan, R.-N., Ghazala, N., \& Anjum, N. (2011). A Study of Relationship between Achievement Motivation, Academic Self Concept and Achievement in English and Mathematics at Secondary Level. International Education Studies, 4(3). doi:10.5539/ies.v4n3p72

Barker, E. (2008). The church without and the God within: Religiosity and/or spirituality? In Barker, E. (Ed.), The centrality of religion in social life. Essays in honour of James A. Beckford (pp. 187-202). Aldershot: Ashgate. [e-book].

Bartlett, L., Mendenhall, M., \& Ghaffar-Kucher, A. (2017). Culture in acculturation: Refugee youth's schooling experiences in international schools in New York City. International Journal of Intercultural Relations, 60, 109-119. doi:10.1016/j.ijintrel.2017.04.005

Bernard, M. E. (2004). Emotional resilience in children: Implications for rational emotive education. Romanian Journal of Cognitive and Behavioral Psychotherapies, 4(1), 39-52.

Betancourt, T. S., \& Khan, K. T. (2008). The mental health of children affected by armed conflict: Protective processes and pathways to resilience. International Review of Psychiatry, 20(3), 317-328. doi:10.1080/09540260802090363

Bonanno, G. A., Galea, S., Bucciarelli, A., \& Vlahov, D. (2007). What predicts psychological resilience after disaster? The role of demographics, resources, and life stress. Journal of Consulting and Clinical Psychology, 75(5), 671-682. doi:10.1037/0022006x.75.5.671

Bowen, D., \& Cheng, A. (2017). Losing My Religion? The Impact of Spiritual Cues on Noncognitive Skills. Journal of Catholic Education, 20(1), 152-176. doi:10.15365/joce.2001072016

Brunstein, J. C., \& Heckhausen, H. (2018). Achievement motivation. In Motivation and action (pp. 221-304). Springer, Cham. doi:10.1007/978-3-319-65094-4_6

Chen, C., Elliot, A. J., \& Sheldon, K. M. (2019). Psychological need support as a predictor of intrinsic and external motivation: the mediational role of achievement goals. Educational Psychology, 39(8), 1090-1113. doi:10.1080/01443410.2019.1618442

Clinton, J. (2008). Resilience and recovery. International Journal of Children's Spirituality, 13(3), 213-222. doi:10.1080/13644360802236474

Crawford, E., Wright, M. O., \& Masten, A. S. (2006). Resilience and spirituality in youth. The handbook of spiritual development in childhood and adolescence, 355-370. doi:10.4135/9781412976657.n25

Darychuk, A., \& Jackson, S. (2015). Understanding community resilience through the accounts of women living in West Bank Refugee Camps. Affilia, 30(4), 447-460. doi:10.1177/0886109915572845

Davis, P. S. (2017). Spirituality and Motivation Among Evangelical College Students (Doctoral dissertation). Biola University, California.

Dinesh, N. P., \& Kiran, A. D. (2018). Comparative study of achievement motivation and self-concept of secondary school students. Indian Journal of Positive Psychology, 9(1), 199-201. doi:10.15614/ijpp.v9i01.11773 
Dörnyei, Z., \& Ushioda, E. (2011). Teaching and researching: Motivation (2nd Ed). Harlow, England: Longman Pearson.

Dyer, J. G., \& McGuinness, T. M. (1996). Resilience: Analysis of the concept. Archives of Psychiatric Nursing, 10(5), 276-282. doi:10.1016/s0883-9417(96)80036-7

Ennis, S. (2011). Religion, spirituality and the refugee experience (Doctoral dissertation). RMIT University, Victoria, Australia. Retrieved from https:// researchbank.rmit.edu.au/view/rmit:160265

Faigin, C. A., \& Pargament, K. I. (2011). Strengthened by the spirit: Religion, spirituality, and resilience through adulthood and aging. In B. Resnick, L. P. Gwyther, \& K. A. Roberto (Eds.), Resilience in Aging (pp. 163-180). New York, NY: Springer. doi:10.1007/978-1-4419-0232-0_11

Florczak, K. L. (2010). Gathering Information on Spirituality. Nursing Science Quarterly, 23(3), 201-205. doi:10.1177/0894318410371836

Garmezy, N. (1993). Children in Poverty: Resilience Despite Risk. Psychiatry, 56(1), 127136. doi:10.1080/00332747.1993.11024627

Gozdziak, E. M., \& Shandy, D. J. (2002). Editorial introduction: Religion and spirituality in forced migration. Journal Refugee Studies, 15, 129-135. doi:10.1093/jrs/15.2.129

Grine, F., Fares, D., \& Meguellati, A. (2015). Islamic spirituality and entrepreneurship: A case study of women entrepreneurs in Malaysia. The Journal of Happiness $\mathcal{E}$ WellBeing, 3(1), 41-56.

Hamdan, A. (2010). A comprehensive contemplative approach from the Islamic tradition. In T. G. Plante (Ed.), Contemplative practices in action: Spirituality, meditation, and health (p. 122-142). Praeger/ABC-CLIO.

Hamza, A.(2014). What is Islamic spirituality? workshops and online seminars.

Harris, L. S. (2016). Effects of Gender and Spirituality on Adultsâ?? Resilience to Daily Nontraumatic Stressors. (Doctoral dissertation). Walden University, Minnesota. Retrieved from https://scholarworks.waldenu.edu

Hawa, S. (2006). Almostaklas Fi Taziatul Anfos (The clarity in the purification of the souls). Cairo, Egypt: Dar Alsalam.

Helgeson, V. S. (2005). Recent Advances in Psychosocial Oncology. Journal of Consulting and Clinical Psychology, 73(2), 268-271. doi:10.1037/0022-006x.73.2.268

Henry, D. L. (1999). Resilience in maltreated children: Implications for special needs adoption. Child Welfare, 78(5).

Husain, S. A. (1998). Religion and mental health from the muslim perspective. Handbook of Religion and Mental Health, 279-290. doi:10.1016/b978-012417645-4/50087-0

Hutchinson, M., \& Dorsett, P. (2012). What does the literature say about resilience in refugee people? Implications for practice. Journal of Social Inclusion, 3(2), 55. doi:10.36251/josi.55

Islahi, S. D. (1989). Islam at a glance (3rd ed.). Lahore, Pakistan: Islamic Publications.

Isokääntä, S., Koivula, K., Honkalampi, K., \& Kokki, H. (2019). Resilience in children and their parents enduring pediatric medical traumatic stress. Pediatric Anesthesia, 29(3), 218-225. doi:10.1111/pan.13573

Jaranson, J. M., Butcher, J., Halcon, L., Johnson, D. R., Robertson, C., Savik, K., ... Westermeyer, J. (2004). Somali and Oromo Refugees: Correlates of Torture and Trauma History. American Journal of Public Health, 94(4), 591-598. doi:10.2105/ajph.94.4.591

Johnson, B. R. (2008). A tale of two religious effects: Evidence for the protective and prosocial impact of organic religion. In Authoritative communities (pp. 187-225). Springer, New York, NY. doi:10.1007/978-0-387-72721-9_9 
Khan, S. (2018). Impartiality and the forgotten crises in Yemen and Myanmar. Maecenata Institut, 34

Kim, S., \& Esquivel, G. B. (2011). Adolescent spirituality and resilience: Theory, research, and educational practices. Psychology in the Schools, 48(7), 755-765. doi:10.1002/ pits.20582

Kobasa, S. C. (1979). Stressful life events, personality, and health: An inquiry into hardiness. Journal of Personality and Social Psychology, 37(1), 1-11. doi:10.1037/0022-3514.37.1.1

Landrum, C. (2000, March). Spirituality of older adults: Expanding the norms of an existing instrument. Paper presented at the Annual Conference of the American Counseling Association, Washington, DC.

Luthar, S. S., Cicchetti, D., \& Becker, B. (2000). The Construct of Resilience: A Critical Evaluation and Guidelines for Future Work. Child Development, 71(3), 543-562. doi:10.1111/1467-8624.00164

Luthar, S. S., Sawyer, J. A., \& Brown, P. J. (2006). Conceptual Issues in Studies of Resilience: Past, Present, and Future Research. Annals of the New York Academy of Sciences, 1094(1), 105-115. doi:10.1196/annals.1376.009

Maslow, A. H. (1954). Motivation and personality Harper and Row. New York, NY.

Masten, A. S. (1994). Resilience in individual development: Successful adaptation despite risk and adversity: Challenges and prospects. In Educational resilience in inner city America: Challenges and prospects (pp. 3-25). Lawrence Erlbaum.

Masten, A. S. (2001). Ordinary magic: Resilience processes in development. American Psychologist, 56(3), 227-238. doi:10.1037/0003-066x.56.3.227

Masten, A. S. (2014a). Global perspectives on resilience in children and youth. Child development, 85(1), 6-20. doi: 10.1111/cdev.12205

Masten A. S. (2014b) Ordinary magic: Resilience in development. New York: Guilford Press.

Masten, A. S., Cutuli, J. J., Herbers, J. E., \& Reed, M.-G. J. (2009). Resilience in Development. The Oxford Handbook of Positive Psychology, pp. 116-132. doi:10.1093/oxfordhb/9780195187243.013.0012

Masten, A. S., Morison, P., Pellegrini, D., \& Tellegen, A. (1990). Competence under stress: risk and protective factors. Risk and Protective Factors in the Development of Psychopathology, 236-256. doi:10.1017/cbo9780511752872.015

McClelland, D. C. (1961). The achieving society. New York, NY, US: D Van Nostrand Company. doi:10.1037/14359-000

McClelland, D. C., Atkinson, J. W., Clark, R. A., \& Lowell, E. L. (1953). The achievement motive. East Norwalk, CT, US: Appleton-Century-Crofts. doi:10.1037/11144-000

Mahudin, N., Noor, N., Dzulkifli, M., \& Janon, N. (2016). Religiosity among Muslims: A Scale Development and Validation Study. Hubs-Asia, 20(2), 109. doi:10.7454/mssh.v20i2.480

Muslim, I. (1978). Sahih Muslim (AH Siddiqi, Trans.). New Delhi, India: Kitab Bhavan.

Nasr, S. H. (1981). The interior life in Islam. Al-Serat, 3(2\&3). Retrieved from http://www.al-islam.org/al-serat.

Nasr, S. H. (1987). Science and civilization in Islam (2nd ed.). Cambridge: The Islamic Texts Society.

Nasr, S. H. (2002). The heart of Islam: Enduring values for humanity. New York: HarperSanFrancisco.

Neenan, M. (2017). Developing resilience: A cognitive-behavioural approach. Taylor $\mathcal{E}$ Francis. doi:10.4324/9781315189178 
Nisar, F., Farwa, M. U., \& Nadeem, S. (2015). spiritual impacts of Islamic beliefs and worships to address psychologica; problems. The Government: Research Journal of Political Science, 4(4).

Pahlevan, S. S., \& Ong, F. S. (2018). Education Moderates the Relationship Between Spirituality with Quality of Life and Stress Among Malay Muslim Women with Breast Cancer. Journal of Religion and Health, 58(4), 1060-1071. doi:10.1007/s10943018-0587-1

Panter-Brick, C., Grimon, M. P., \& Eggerman, M. (2014). Caregiver - Child mental health: A prospective study in conflict and refugee settings. Journal of Child Psychology and Psychiatry, 55(4), 313-327. doi:10.1111/jcpp.12167

Pastoor, L. de W. (2017). Reconceptualising refugee education: exploring the diverse learning contexts of unaccompanied young refugees upon resettlement. Intercultural Education, 28(2), 143-164. doi:10.1080/14675986.2017.1295572

Patel, S. G., Staudenmeyer, A. H., Wickham, R., Firmender, W. M., Fields, L., \& Miller, A. B. (2017). War-exposed newcomer adolescent immigrants facing daily life stressors in the United States. International Journal of Intercultural Relations, 60, 120 131. doi:10.1016/j.ijintrel.2017.03.002

Peres, J. F. P., Moreira-Almeida, A., Nasello, A. G., \& Koenig, H. G. (2007). Spirituality and Resilience in Trauma Victims. Journal of Religion and Health, 46(3), 343-350. doi:10.1007/s10943-006-9103-0

Pieloch, K. A., McCullough, M. B., \& Marks, A. K. (2016). Resilience of children with refugee statuses: A research review. Canadian Psychology/Psychologie Canadienne, 57(4), 330-339. doi:10.1037/cap0000073

Poledňová, I., Stránská, Z., \& Niedobová, H. (2014). Achievement motivation of secondary school students in relation to their social position in the class. Problems of Psychology in the 21st Century, 8(1), 61-70.

Pulla, V. (2014). Spiritually sensitive social work: The road worth taking. Social Work Edciation and Practice. Australia: Primrosehall Publishing, pp. 182-200.

Quispe-Bendezú, L. E., Araujo-Castillo, R. L., García-Tejada, J. E., García-Tejada, Y., Sprock, A. S., \& Villalba-Condori, K. O. (2020). Relationship between Academic Procrastination and Attributions of Achievement Motivation. International Journal of Learning, Teaching and Educational Research, 19(1), 188-205. doi:10.26803/ijlter.19.1.11

Rak, C. F., \& Patterson, L. E. (1996). Promoting Resilience in At-Risk Children. Journal of Counseling \& Development, 74(4), 368-373. doi:10.1002/j.1556-6676.1996.tb01881.x

Rassool, G. H. (2000). The crescent and Islam: healing, nursing and the spiritual dimension. Some considerations towards an understanding of the Islamic perspectives on caring. Journal of Advanced Nursing, 32(6), 1476-1484. doi:10.1046/j.1365-2648.2000.01614.x

Rego, F., \& Nunes, R. (2019). The interface between psychology and spirituality in palliative care. Journal of Health Psychology, 24(3), 279-287. doi:10.1177/1359105316664138

Richardson, G. E., Neiger, B. L., Jensen, S., \& Kumpfer, K. L. (1990). The Resiliency Model. Health Education, 21(6), 33-39. doi:10.1080/00970050.1990.10614589

Robertson, C. L., Halcon, L., Savik, K., Johnson, D., Spring, M., Butcher, J.,... Jaranson, J. (2006). Somali and Oromo refugee women: Trauma and associated factors. Journal of Advanced Nursing, 56, 577-587. doi:10.1111/j.1365-2648.2006.04057.x

Robinson, R. V. (2013). Pathways to resilience in the context of Somali culture and forced displacement (Doctoral dissertation). University of Alaska Anchorage.

Rutter, M. (1987). Developmental Psychiatry (1st American Psychiatric Press Ed.,). Washington, DC: American Psychiatric Press. 
Sani, A., \& Maharani, E. V. (2019). Spirituality at work and organizational commitment as moderating variables in relationship between Islamic spirituality and OCB IP and influence toward employee performance. Journal of Islamic Marketing. doi:10.1108/jima-08-2018-0140

Shaw, S. A., Peacock, L., Ali, L. M., Pillai, V., \& Husain, A. (2019). Religious Coping and Challenges Among Displaced Muslim Female Refugees. Affilia, 34(4), 518-534. doi:10.1177/0886109919866158

Shekhar, C., \& Rachna, D. (2012). Achievement Motivation across Gender and Different Academic Majors. Journal of Educational and Developmental Psychology, 2(2), 105109. doi:10.5539/jedp.v2n2p105

Smith, B. W., Tooley, E. M., Christopher, P. J., \& Kay, V. S. (2010). Resilience as the ability to bounce back from stress: A neglected personal resource? The Journal of Positive Psychology, 5(3), 166-176. doi:10.1080/17439760.2010.482186

Southwick, S. M., \& Charney, D. S. (2012). Resilience - The science of mastering life's greatest challenges. Cambridge, UK: Cambridge University Press.

Stokley, F. J. (2002). What It Means To Be a Spiritual Leader. School Administrator, 59(8), 48-50.

Bal-Taştan, S., Davoudi, S. M. M., Masalimova, A. R., Bersanov, A. S., Kurbanov, R. A., Boiarchuk, A. V., \& Pavlushin, A. A. (2018). Correction on The Impacts of Teacher's Efficacy and Motivation on Student's Academic Achievement in Science Education among Secondary and High School Students. EURASIA Journal of Mathematics, Science and Technology Education, 14(12). doi:10.29333/ejmste/97832

Tirmidhi, Abu Isa Muhammad Bin Isa Bin Sawrah al. (1999). Jami' alTirmidhi. Riyad, KSA: Dar al-Salam.

United Nations High Commissioner for Refugees. (2018). Retrieved from http://www.refworld.org/docid/512c75de2.html [accessed 24 August 2018].

Ungar, M. (2012). Social ecologies and their contribution to resilience. In The social ecology of resilience (pp. 13-31). Springer, New York, NY. doi:10.1007/978-1-4614-0586-3_2

United Nations High Commissioner for Refugees. (2016). Yemen: UNHCR Regional Update , Retrieved from https:// www.refworld.org/docid/562f316f4.html

United Nations High Commissioner for Refugees. (2018). Global trends 2017. Geneva, Switzerland

United Nations High Commissioner for Refugees. (2020). 2020 Planing summary. Retrieved from http://reporting.unhcr.org/yemen

Van der Veer, G. (1992). Counselling and therapy with refugees: Psychological problems of victims of war, torture and repression. John Wiley $\mathcal{E}$ Sons.

Waxman H. C., Gray J. P., \& Padron Y. N. (2003). Review of Research on Educational Resilience: Research Report. Washington, DC: Institute of Education Sciences.

Werner, E., \& Smith, R. (1992) Overcoming the Odds: High Risk Children from Birth to Adulthood. Ithaca, New York: Cornell University Press.

Wolin, S. J., \& Wolin, S. (2010). The resilient self: How survivors of troubled families rise above adversity. Villard.

Wong, C. W. S., \& Schweitzer, R. D. (2017). Individual, premigration and postsettlement factors, and academic achievement in adolescents from refugee backgrounds: A systematic review and model. Transcultural Psychiatry, 54(5-6), 756-782. doi:10.1177/1363461517737015

Wright, A. (2003). Spirituality and Education, Master classes in education series. Psychology Press.

Zsolnai, L., \& Illes, K. (2017). Spiritually inspired creativity in business. International Journal of Social Economics, 44(2), 195-205. doi:10.1108/ijse-06-2015-0172 